\title{
REEXISTÊNCIAS CONSTRUIDAS NA TERRA: AGROECOLOGIA $x$ AGRONEGÓCIO
}

\author{
RE-EXISTENCES BUILT ON EARTH: \\ AGROECOLOGY $x$ AGRIBUSINESS
}

Marciele Neres de Jesus ${ }^{1}$

Desenvolvimento sustentável

Trabalho e educação,

Juntos alinhados

Com a mesma intenção.

Alertar as pessoas

Os perigos em atuação,

Envolvendo o agronegócio,

As formas de trabalho e submissão.

Trabalhando para latifundiários

Muitos trabalhadores vivem a opressão,

Negação da sua cultura,

Invisibilidade e contaminação.

O trabalho é realizado

Com mão de obra barata e exploração,

Degradação do meio ambiente

E adoecimento da população.

Agricultura familiar

E agronegócio em questão.

É preciso refletir

E escolher a melhor opção.

\footnotetext{
${ }^{1}$ Atualmente é Mestranda no Programa de pós Graduação em Educação da Universidade Estadual do Sudoeste Bahia (PPGED/UESB). Pedagoga (UNEB-Campus XII). e-mail: marcieleneres@gmail.com
} 
O agronegócio produz

Por meio da monocultura.

Enquanto a agroecologia

Cresce com a policultura.

O agronegócio manipula,

Tira o direito do cidadão,

Faz o povo acreditar

$\mathrm{Na}$ sua forma de produção.

O "veneno tá na mesa",

É consumido todos os dias,

Fazendo com que as pessoas

Não sejam mais sadias.

Nessa terra em disputa

Vence quem tem capital.

Essa terra é para poucos

Desde o período colonial.

Em busca de mais terras

Para cada dia expandir,

As terras dos camponeses

Começaram a invadir.

Agro é manipulação,

Agro é desmatamento,

Agro é grilagem de terras,

Isso não é desenvolvimento.

$\mathrm{O}$ verdadeiro desenvolvimento

É aquele em que todos podem crescer,

O povo exerce a soberania

E podem desenvolver.

Em defesa da vida

Temos a agricultura familiar.

Mas vem o agronegócio

Com o intuito de a derrubar. 
Você pensa que não há saída Para mudar a situação?

A resposta é a agroecologia

Como meio de produção.

$\mathrm{O}$ pequeno agricultor

Trabalha para o próprio sustento,

Usa recursos naturais

Para produzir seu alimento.

A educação no/do campo

Ensina o agricultor a resistir.

Por meio das lutas por direitos

A agroecologia irá persistir.

Na sociedade atual

O trabalho tem sido para sobreviver,

Com os trabalhos alienados

Muitos deixaram de viver.

O sistema capitalista

Dita como deve ser.

Sem tempo para nada

$\mathrm{O}$ povo está a adoecer.

Com grandes jornadas de trabalho

Surgem ansiedade e depressão,

E cada dia mais doente

Se encontra essa nação.

Um modelo mata o povo

$\mathrm{O}$ outro incentiva a viver.

Cabe a todos a missão

Da melhor forma escolher.

A sustentabilidade que queremos

Não é a que faz o capitalismo crescer,

Mas a que valoriza o semiárido

$\mathrm{E}$ as formas de aqui viver. 
O trabalho que o povo precisa

Não é o que faz ele perecer.

É preciso trabalho digno

Sem precisar sofrer.

E assim todos juntos

Podem desenvolver,

Se alimentar de forma saudável

Trabalhar e ter lazer.

$\mathrm{O}$ pequeno agricultor

Na luta sempre estar.

A união é o que fortalece

Essa luta popular.

Recebido: 08/04/2021

Aprovado: 30/11/2021 